\title{
Multiphasic CT and MR Imaging Findings of an Isolated Transverse Colon Hemangioma
}

\author{
Bohyun Kim \\ Department of Radiology, Seoul St. Mary's Hospital, College of Medicine, The Catholic University of Korea, Seoul, Korea
}

Colonic hemangiomas are rare benign mesenchymal tumors but can potentially cause a life-threatening bleeding. Although phlebolith on simple radiography or CT scan is a pathognomonic sign of colonic hemangioma, it may not be always present. With wider use of cross-sectional images, it is necessary to know the imaging findings of the colonic hemangiomas on multiphasic scan and MRI for the correct diagnosis and management of the disease.

Keywords: Hemangioma; Colon; Magnetic resonance imaging; Computed tomography

\section{Introduction}

Gastrointestinal (GI) tract hemangiomas are rare benign mesenchymal tumors, and may manifest as various degree of hemorrhage ranging from occult to life-threatening bleeding. While surgical resection is regarded as a definitive treatment of the disease, preoperative biopsy is contraindicated due to the risk of bleeding. Thus, acknowledging the radiologic findings of GI tract hemangiomas may help in diagnosis and patient management. Herein, a rare case of a transverse colon hemangioma is presented focusing on endoscopic findings and imaging features on cross-sectional images.

\section{Case Report}

A 63-year-old female patient was referred to our hospital for the evaluation of a colonic mass discovered during a screening colonoscopy. The patient was asymptomatic, and physical examination showed no abnormality. Routine laboratory tests were all within the normal range, including a hemoglobin of $13.3 \mathrm{~g} / \mathrm{dL}$. The level of tumor markers were also within the normal range, with carcinoembryonic antigen of $2.28 \mathrm{ng} / \mathrm{mL}$ and carbohydrate antigen 19-9 of $3.12 \mathrm{U} / \mathrm{mL}$.

On colonoscopy, there was an approximately $3 \mathrm{~cm}$ elevated mass at the distal transverse colon having a purplish red to blue surface and an erythematous central depression (Fig. 1).

Multiphasic CT revealed a $2.7-\mathrm{cm}$ sized lobulated and exophytic mass that rested on the cranial side of the transverse colon (Fig. 2). On noncontrast scan, the mass showed homogeneous attenuation without calcification or hemorrhage. On dynamic enhancement study, the mass

\footnotetext{
Received: June 6, 2021 Revised: June 27, 2021 Accepted: June 27, 2021

Correspondence: Bohyun Kim, MD, PhD

Department of Radiology, Seoul St. Mary's Hospital, College of Medicine, The Catholic University of Korea, 222 Banpo-daero, Seocho-gu,

Seoul 06591, Korea

Tel: +82-2-2258-5793 Fax: +82-2-599-6771 E-mail: kbh@catholic.ac.kr

This is an Open Access article distributed under the terms of the Creative Commons Attribution Non-Commercial License (http:// creativecommons.org/licenses/by-nc/4.0/) which permits unrestricted non-commercial use, distribution, and reproduction in any medium, provided the original work is properly cited.
} 


\section{KJAR}

showed subtle progressive enhancement from the center to the periphery (Fig. 2). There was no sign of colonic obstruction. There was no remarkable findings in the solid organs. No enlarged lymph node was noticed in the abdomen and pelvis.

MRI more clearly demonstrated lobulated contour of the mass that showed hyperintense T2 signal (Fig. 3). There was no remarkable diffusion restriction in the mass. Similar to the enhanced $\mathrm{CT}$, the central portion of the mass showed more prominent enhancement.

Based on these findings, preliminary diagnosis of colonic hemangioma was given. Because of the risk of bleeding, diagnostic and therapeutic laparoscopic colectomy was planned after a multidisciplinary team discussion. Laparoscopic exploration revealed a $2 \mathrm{~cm}$ mass-like lesion

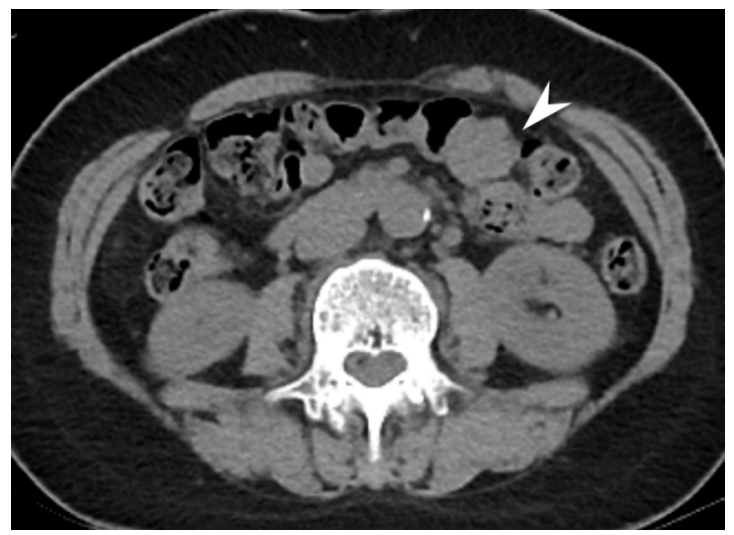

A

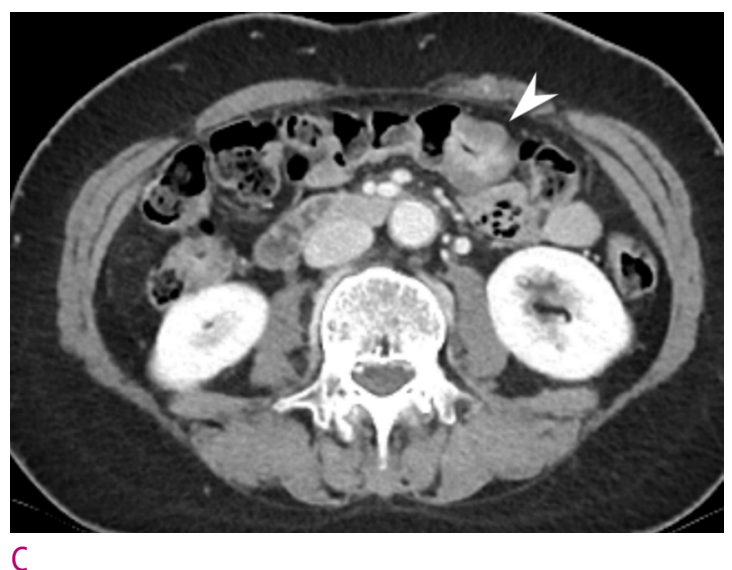

Imaging Findings of Colonic Hemangiomas | Bohyun Kim

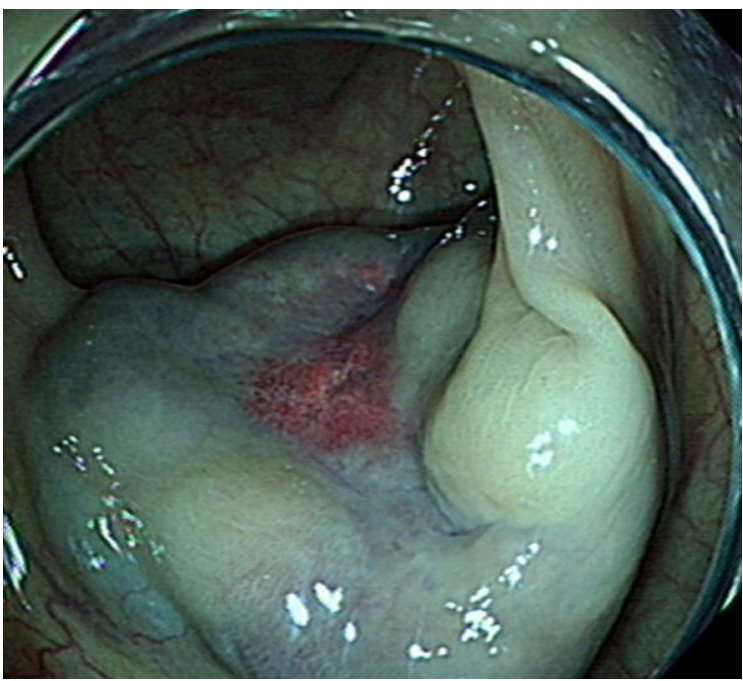

Fig. 1. Colonoscopy shows an elevated mass with a purplish red to blur surface and an erythematous central depression.

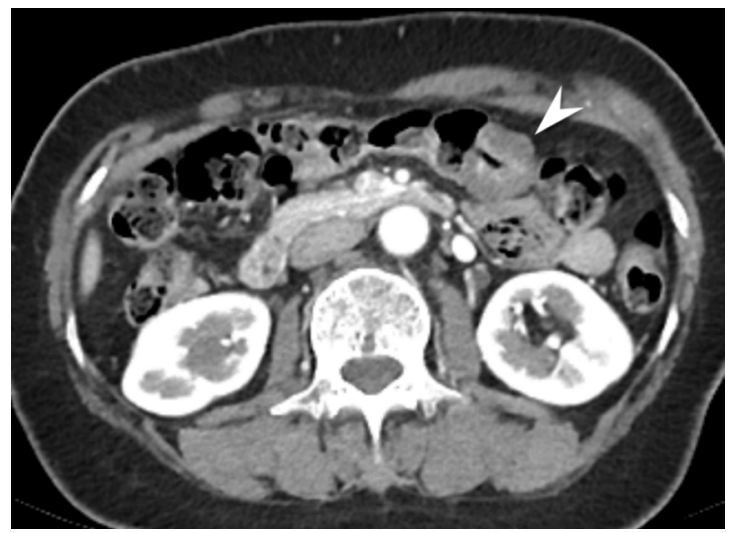

B

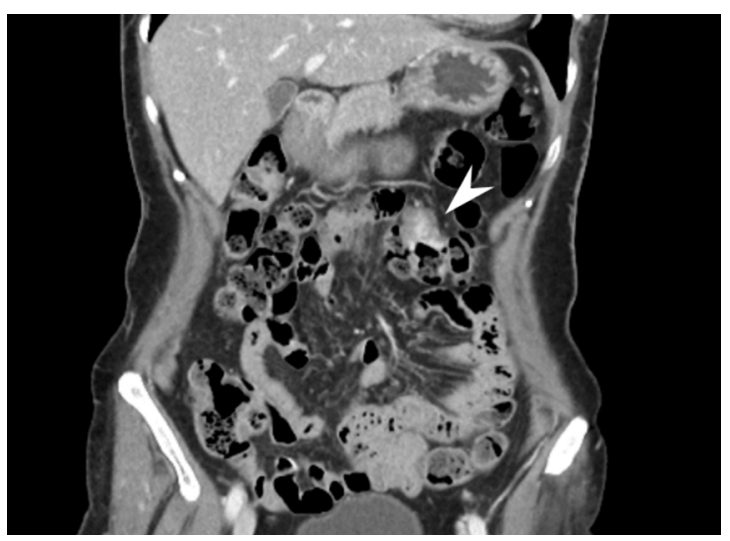

D

Fig. 2. Multiphasic $C T$ reveals a $2.7 \mathrm{~cm}$ mass (arrowheads) in the distal transverse colon. On noncontrast CT scan (A), the mass show homogeneously low attenuation without calcifications or hemorrhage. Arterial (B) and portovenous (C) phases show a subtle and progressive enhancement that begins from the center of the mass. Coronal multiplanar reformation image (D) indicates that the mass is located on the serosal side of the transverse colon and having an exophytic growth. 


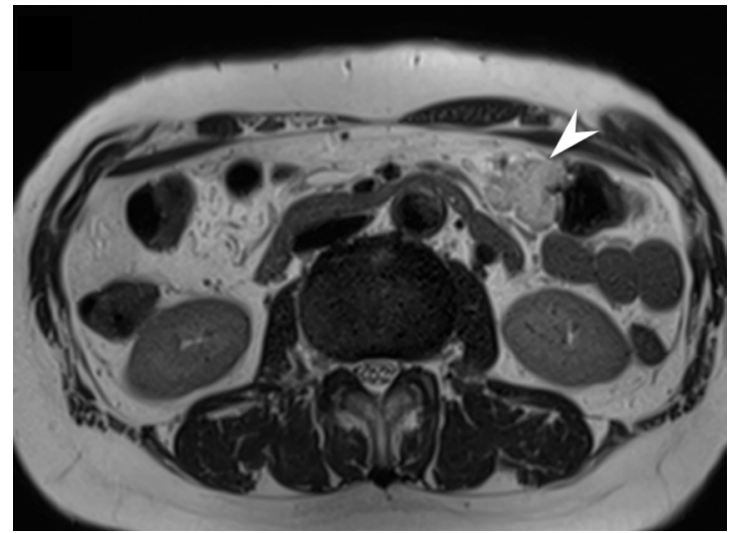

A

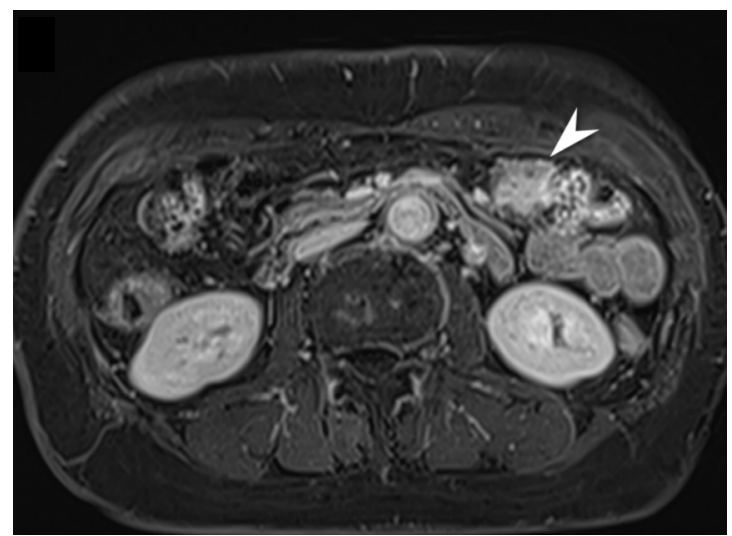

C

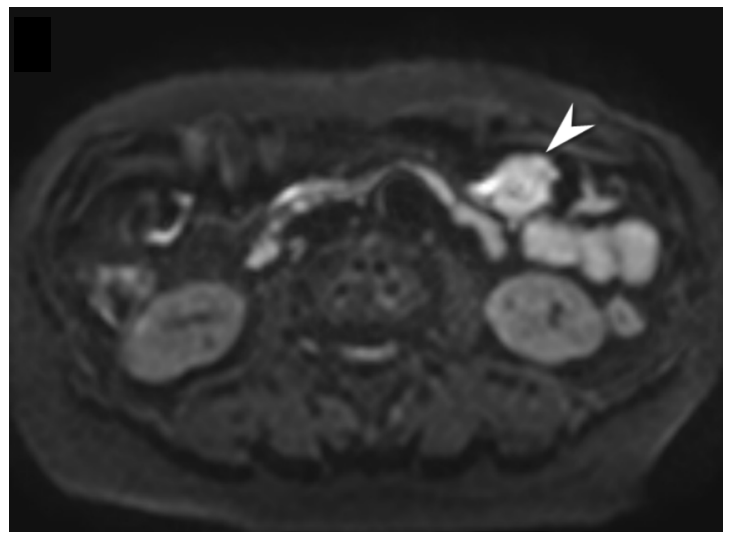

$\mathrm{E}$

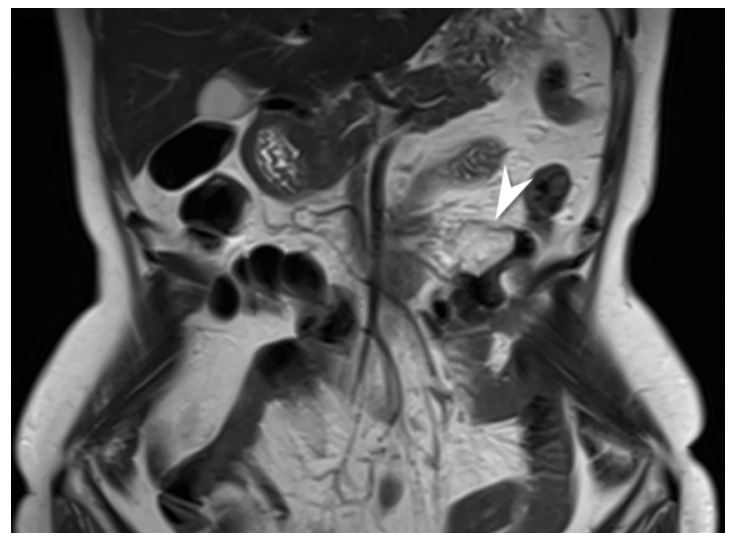

B

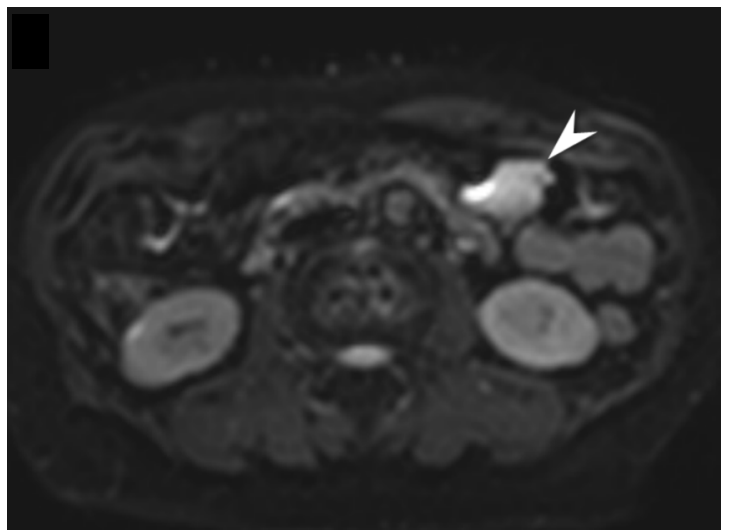

D

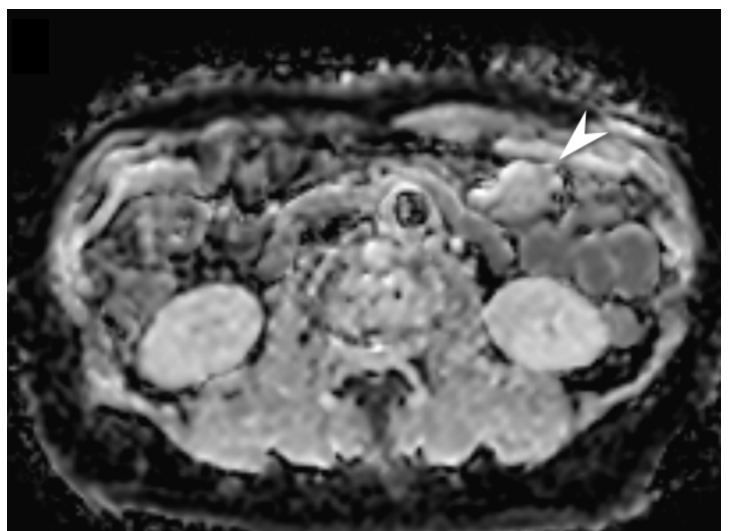

$\mathrm{F}$

Fig. 3. MR images show a lobulated mass (arrowheads) in the distal transverse colon. Axial (TR, $900 \mathrm{~ms}$; TE, $82 \mathrm{~ms}$ ) (A) and coronal (TR, $900 \mathrm{ms;}$ TE, 111 ms) (B) T2-weighted HASTE images show a well-defined and lobulated mass with a high T2 signal intensity. Enhanced axial T1-weighted image (C) shows more prominent enhancement in the center of the mass. No remarkable diffusion restriction was noticed on diffusion weighted images with b values of $0 \mathrm{~s} / \mathrm{mm}^{2}(D), 800 \mathrm{~s} / \mathrm{mm}^{2}(E)$, and corresponding ADC map (F).

composed of conglomerated and engorged vascular structure at the serosal side of the transverse colon. Approximately $8 \mathrm{~cm}$ of the colon that contained the mass was resected without complication, and the patient was discharged on the sixth postoperative day.

Histopathologic examination of the resected specimen 

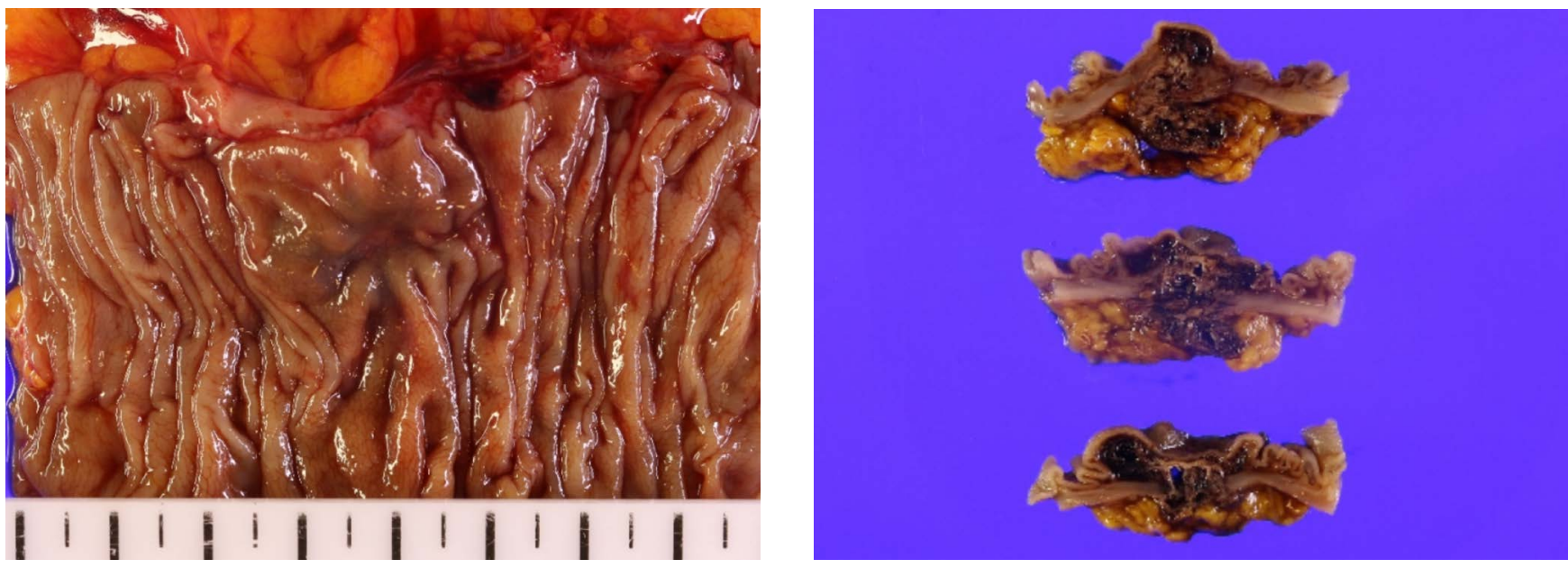

Fig. 4. Surgical and pathologic specimens show a submucosal mass comprised of engorged vascular structure, indicating cavernous hemangioma.

indicated a $2.5 \mathrm{~cm}$ spongiotic cavernous hemangioma located in the submucosal layer of the transverse colon (Fig. 4). Immunohistochemical examination excluded possibilities of adenocarcinoma, lymphoma or other mesenchymal tumor.

\section{Discussion}

GI tract hemangiomas are rare benign mesenchymal tumors, accounting for $0.3 \%$ of all $\mathrm{Gl}$ tract tumors. GI tract hemangiomas comprise proliferations of lymphatics, capillaries, or veins within the mucosa or submucosa (1). They can occur singly or multiply anywhere from the esophagus to the rectum, but the most common site is the small intestine followed by the rectosigmoid colon $(1,2)$. Approximately $80 \%$ of colonic hemangiomas are cavernous subtype having relatively circumscribed proliferations of large and often dilated thin-walled vessels or blood-filled sinuses which may contain thrombus $(1,3)$. These features give typically purplish-red to blue surface of the tumor that is soft and compressible on touch on endoscopy $(2,4,5)$. Clinically, $60-90 \%$ of the patients with GI tract hemangiomas present with occult or lifethreatening bleeding, while approximately $10 \%$ of the patients can be asymptomatic $(3,6)$. Other symptoms include anemia from chronic bleeding, abdominal or pelvic pain, and intestinal obstruction (4).

GI tract hemangiomas may show polypoid intraluminal or diffusely infiltrative growths involving both intraluminal and extraserosal sides on gross pathology, and these appearances are readily reflected on cross-sectional imaging studies (2). CT shows wall thickening of the involved segment and phlebolith, which is an important clue to the diagnosis of a Gl tract hemangioma (2). Engorgement of adjacent mesenteric vessels and progressive nodular enhancement of the colonic wall are observed on enhanced CT or MRI (6). On T2-weighted MRI images, thickened bowel wall shows high signal intensity from distended vascular spaces $(4,7)$. Although no prior reports described findings on diffusion weighted images, no remarkable diffusion restriction as have demonstrated in current case may help in distinguishing GI tract hemangiomas from colon cancers or gastrointestinal stromal tumors.

Biopsy prior to surgery may cause severe hemorrhage and is usually not recommended $(4,7)$. Therefore, surgical resection is performed for the diagnosis and definitive treatment of the $\mathrm{Gl}$ tract hemangiomas in general. In a rare pedunculated hemangioma, colonoscopic polypectomy can be considered (8). For hemangiomas located in rectosigmoid colon, sphincter preserving low anterior resection or segmental resection is performed. In more proximal lesions, segmental resection or wedge resection is advised (4).

ORCID: Bohyun Kim: https://orcid.org/0000-0003-1157-415X

\section{References}

1. Fukayama M, Goldblum JR, Miettinen M, Lazar AJ. 
Mesenchymal tumours of the digestive system. In: Klimstra DS, Lam AK, Paradis V, Schimacher P, eds. WHO classification of tumours of the digestive system, 5th ed. Lyon: International Agency for Research on Cancer, 2019:434-498.

2. Levy $A D$, Abbott RM, Rohrmann $C A$, Jr., Frazier $A A$, Kende A. Gastrointestinal hemangiomas: imaging findings with pathologic correlation in pediatric and adult patients. AJR Am J Roentgenol 2001;177:1073-1081.

3. Marinis A, Kairi E, Theodosopoulos T, Kondi-Pafiti A, Smyrniotis $V$. Right colon and liver hemangiomatosis: a case report and a review of the literature. World J Gastroenterol 2006;12:6405-6407.

4. Yoo S. GI-Associated Hemangiomas and Vascular Malformations. Clin Colon Rectal Surg 2011;24:193-200.

5. Zhang M-G, Lu Z, Wang Y, Redati D, Zheng Z, Wang X. A Rare Case of Transverse Colonic Cavernous Hemangioma: An
Ambiguous Preoperative Diagnosis, An Inappropriate Biopsy, A Fortunate Outcome, One Good Lesson and Some Serious Reflections. Medical Case Reports 2018;04.

6. Shen J-D, Chen C-W, Chen T-A, Yueh T-C. Colonic hemangioma, a diagnostic challenge in young adults with lower gastrointestinal tract bleeding. Formosan Journal of Surgery 2016;49:238-241.

7. Kim KH, Kim HK, Lee HK, Shim JC, Lee GJ, Lee KE, et al. Imaging Findings of Cavernous Hemangioma Arising from the Transverse Colon: A Case Report. Journal of the Korean Society of Radiology 2013;69.

8. Ogasawara N, Suzuki M, Adachi K, Yamaguchi Y, Yamamoto $S$, Hijikata $Y$, et al. Endoscopic Resection of a Pedunculated Cavernous Hemangioma of the Sigmoid Colon: A Case Report. Case Rep Gastroenterol 2019;13:418-422.

\title{
횡행결장 혈관종의 다중시기 조영증강 컴퓨터단층촬영영상과 자기공명영상 검사 소견
}

\author{
김보현 \\ 가톨릭대학교 서울성모병원 영상의학과
}

\section{초 록}

대장 혈관종은 드문 양성 중간엽 종양이나 생명을 위협하는 심한 위장관 출혈을 일으킬 수 있다. 대장 혈관종의 주요 영상 소견인 정맥돌 (phlebolith)은 단순 방사선 촬영이나 컴퓨터 단층촬영을 통해 확인 할 수 있으나 항상 있는 것은 아니다. 본 증례는 대장 내시경에서 전형적인 소견을 보여 대장 혈관종으로 강력히 의심했으나 영상검사에서는 정맥 돌이 없어 진단에 혼란이 있었던 드문 대장 혈관종의 예이다. 